\title{
Specific regulation of Xenopus chromosomal 5S rRNA gene transcription in vivo by histone $\mathrm{H1}$
}

\author{
Philippe Bouvet, Stefan Dimitrov, and Alan P. Wolffe \\ Laboratory of Molecular Embryology, National Institute of Child Health and Human Development, National Institutes \\ of Health, Bethesda, Maryland 20892 USA
}

\begin{abstract}
The incorporation of histone $\mathrm{H1}$ into chromatin during embryogenesis directs the specific repression of the Xenopus oocyte $5 \mathrm{~S}$ rRNA genes. An increase in histone $\mathrm{H1}$ content specifically restricts TFIIIA-activated transcription, and a decrease in histone $\mathrm{H1}$ within chromatin facilitates the activation of the oocyte 5S rRNA genes by TFIIIA. Variation in the amount of histone $\mathrm{H1}$ in chromatin does not significantly influence somatic 5S rRNA gene transcription. Thus, the regulated expression of histone H1 during Xenopus development has a specific and dominant role in mediating the differential expression of the oocyte and somatic 5S rRNA genes. This example demonstrates that histones can exert dominant repressive effects on the transcription of a gene in vivo in spite of an abundance of transcription factors for that gene.
\end{abstract}

[Key Words: Xenopus; TFIIIA; histone H1; chromatin; transcription; ribozyme]

Received November 30, 1993; revised version accepted March 28, 1994.

Impressive genetic evidence exists for the histone proteins having a supporting role in gene regulation /Grunstein 1990; Felsenfeld 1992; Herskowitz et al. 1992; Winston and Carlson 1992). Nucleosomes are recognized as potentially restricting the access of trans-acting factors to DNA (Adams and Workman 1993); this restriction can depend on the positioning of histones with respect to DNA sequence and on the modifications of the histones (Simpson 1991; Lee et al. 1993; Turner 1993). Histones and their modifications are also involved in establishing the structure and function of chromosomal domains (Braunstein et al. 1993; Renauld et al. 1993; Turner 1993). Nevertheless, a role for an individual histone in regulating the expression of a specific gene during a developmental process has not yet been established.

Linker histones such as $\mathrm{H} 1$ play a key role in the compaction of nucleosomes into the chromatin fiber (Thoma et al. 1979; Butler and Thomas 1980). They prefer to associate with DNA wrapped around an octamer of core histones rather than with naked DNA (Hayes and Wolffe 1993). Incorporation of a single molecule of linker histone into the nucleosome stabilizes the interaction of $166 \mathrm{bp}$ of DNA with the histones (Simpson 1978; Allan et al. 1980). Linker histones may also influence the positioning of nucleosomes (Meersseman et al. 1991; Chipev and Wolffe 1992). Distinct variants of linker histones are expressed during the development of several organisms, including vertebrates (Poccia 1986). In the sea urchin (Strongylocentrotus), there are distinct sperm, cleavage, and adult linker histones (Newrock et al. 1977; Levy et al. 1982; Knowles et al. 1987; Lai and Childs 1988). In Xenopus laevis during embryogenesis, there is a transition from a cleavage (B4) to an adult $(\mathrm{H} 1)$, to a specialized linker histone found predominantly in terminally differentiated, nondividing cells $\left(\mathrm{H} 1^{\circ}\right)$, (Perry et al. 1985; Smith et al. 1988; Dimitrov et al. 1993; Khochbin and Wolffe 1993). The structural and functional significance of these transitions has not been determined.

Linker histones have been proposed to act as general repressors of transcription (Weintraub 1984). In vitro reconstitution experiments using small DNA templates support this repressive role (Shimamura et al. 1989; Croston et al. 1991; Laybourn and Kadonaga 1991). In vivo, the overexpression of linker histones in somatic cells leads to cell cycle arrest and the reversible inhibition of DNA replication (Sun et al. 1989; Aubert et al. 1991). In contrast to these general inhibitory effects, evidence for a specific role for histone $\mathrm{Hl}$ in gene expression comes from experiments in Xenopus, where removal of histone $\mathrm{HI}$ from the chromosomal chromatin of somatic cells selectively allows transcription factor access to the oocyte 5S rRNA genes (Schlissel and Brown 1984; Wolffe 1989a,b; Chipev and Wolffe 1992).

We have now examined the role of histone $\mathrm{Hl}$ in regulating gene expression during Xenopus embryogenesis. Surprisingly, the expression of many genes encoding small RNAs, including the somatic 5S rRNA genes, is 
unaffected by overexpression of histone $\mathrm{Hl}$ or by deficiency of the protein. Nevertheless, we find that $\mathrm{Hl}$ has a dominant role in selectively repressing the oocyte $5 \mathrm{~S}$ rRNA genes. Our results suggest that histones may exert their repressive effects on transcription even when transcription factors are in excess.

\section{Results}

Histone $H 1$ inhibits the selective activation of chromosomal oocyte $5 S_{r} R N A$ gene expression by TFIIIA

In $X$. laevis $5 \mathrm{~S}$ rRNA gene expression is developmentally regulated (Wakefield and Gurdon 1983; Wormington and Brown 1983; for review, see Wolffe and Brown 1988). The oocyte 5S rRNA genes $(20,000$ per haploid $)$ are active in growing oocytes and transiently active at the mid-blastula transition (MBT) yet are repressed in somatic cells. In contrast, the somatic $5 \mathrm{~S}$ rRNA genes (400 per haploid) are active in oocytes, at the MBT and in somatic cells. These genes share the same transcription factors TFIIIA, TFIIB, and TFIIIC (Segall et al. 1980; Setzer and Brown 1985 ) yet assemble transcription complexes with differential stabilities (Wolffe and Brown 1987). The association of TFIIIA with the 5S rRNA gene is necessary for the subsequent formation of a transcription complex containing TFIIIB and TFIIIC (Setzer and Brown 1985). Transcription factors such as TFIIIA are abundant in growing oocytes (Pelham and Brown 1980; Shastry et al. 1984) yet are limiting for transcription in eggs and embryos (Engelke et al. 1980; Andrews and Brown 1987; Wolffe and Brown 1987). The product of transcription, 5S rRNA, has a role in titrating TFIIIA away from the oocyte 5S rRNA genes during embryogenesis (Rollins et al. 1993). This is because TFIIIA not only associates with the 5S rRNA gene but also with the transcription product, 5S rRNA (Pelham and Brown 1980). Raising the level of TFIIIA in developing Xenopus embryos will stimulate transcription of the oocyte 5S rRNA genes (Brown and Schlissel 1985; Andrews and Brown 1987).

We made use of the capacity to activate chromosomal oocyte $5 \mathrm{~S}$ rRNA gene expression by raising the level of TFIIIA in Xenopus embryos to examine the influence of chromatin on transcription. TFIIIA protein is synthesized following the injection of TFIIIA mRNA into fertilized eggs. Without injection of TFIIIA mRNA, a slight excess of somatic 5S rRNA accumulates relative to oocyte $5 S$ rRNA through gastrulation (Fig. 1, lane 7). Because there are 50 times more oocyte than somatic $5 \mathrm{~S}$ rRNA genes, this represents at least a 50 -fold preference for expression of the somatic genes. With injection of TFIIIA mRNA there is a large ( $>50$-fold $)$ increase in oocyte 5S rRNA accumulation and a much smaller increase $(2$-fold) in somatic $5 S$ rRNA accumulation based on densitometry of the autoradiographs (Fig. 1, cf. lanes 1 and 7 with lanes 2 and 8 ). The oocyte 5S rRNA genes have relatively weak terminators for RNA polymerase III, which leads to a diffuse "tail" of longer transcripts (Bogenhagen and Brown 1981). This increase in oocyte 5S

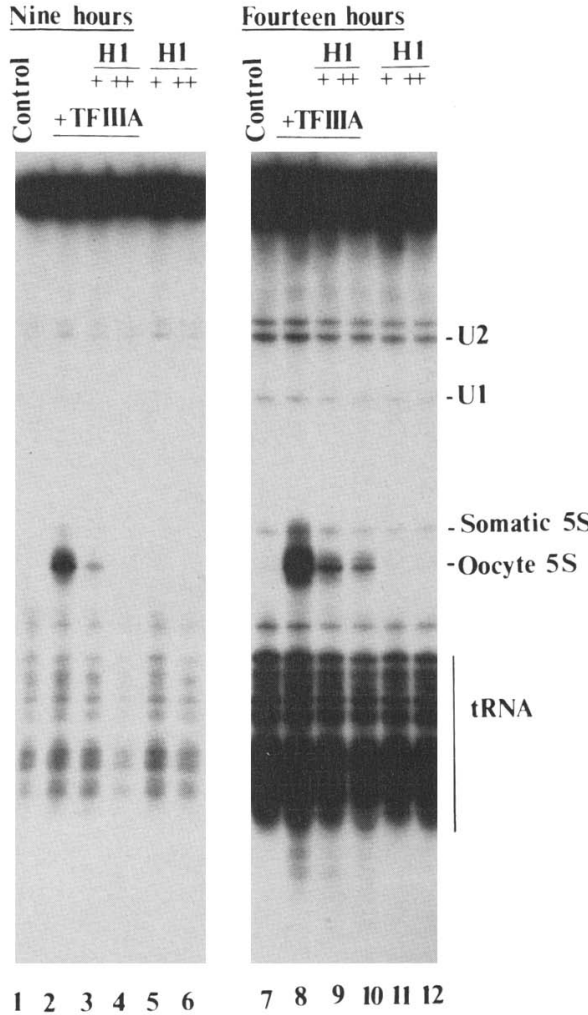

Figure 1. Selective repression of $5 \mathrm{~S}$ oocyte RNA expression in gastrula embryos by injection of H1C mRNA. All embryos were injected with $0.1 \mu \mathrm{Ci}$ of $\left[\alpha^{-32} \mathrm{P}\right] \mathrm{GTP}$. Total nucleic acid from one control embryo (lanes 1,7 ) and mRNA-injected embryos (lanes $2-6,8-12$ ) was separated on a $15 \%$ acrylamide, $4 \mathrm{M}$ urea, $1 \times \mathrm{TBE}$ gel for $24 \mathrm{hr}$ at $10 \mathrm{~mA}$. Embryos were injected with $3 \mathrm{ng}$ of TFIIIA mRNA alone (lanes 2,8), with 3 ng of $\mathrm{HlC}$ mRNA (lanes 5,11 ) or $8 \mathrm{ng}$ of H1C mRNA (lanes 6,12), or injected with $3 \mathrm{ng}$ of TFIIIA RNA and $3 \mathrm{ng}$ of HIC mRNA (lanes 3,9 ) or $3 \mathrm{ng}$ of TFIIIA RNA plus $8 \mathrm{ng}$ of HIC RNA (lanes 4,10 ). Samples of 10 embryos were taken $9 \mathrm{hr}$ (late blastula) or $14 \mathrm{hr}$ (gastrula) after fertilization. The positions of U1, U2, somatic 5S, oocyte 5S RNA, and tRNAs are indicated.

rRNA reflects the maintenance of high levels of TFIIIA protein through gastrulation following injection of TFIIIA mRNA (Fig. 2A, $9 \mathrm{hr}$ ). This result also indicates that TFIIIA is limiting for oocyte 5S rRNA gene transcription and that TFIIIB and TFIIIC are present in excess. In vitro transcription experiments with chromatin isolated from control embryos and from embryos injected with TFIIIA mRNA confirm that this increase in 5S rRNA accumulation is directly attributable to a higher rate of transcription (data not shown; see Andrews and Brown 1987). RNase protection experiments (data not shown; see Fig. 7, below) confirmed that the increase in transcription was from the oocyte $5 \mathrm{~S}$ rRNA genes.

Xenopus eggs sequester histone $\mathrm{H} 1 \mathrm{mRNA}$ but do not synthesize $\mathrm{Hl}$ protein until after fertilization (Woodland et al. 1979). Three variants of histone $\mathrm{H} 1$ accumulate: H1A, H1B, and H1C (Risley and Eckhardt 1981). H1A is 
A

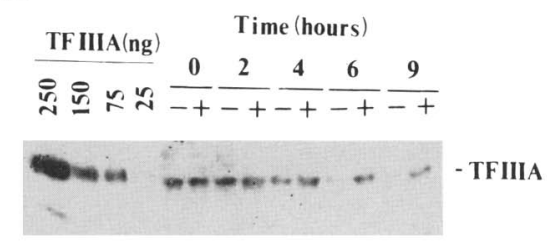

B

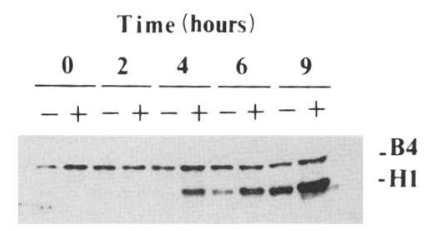

C

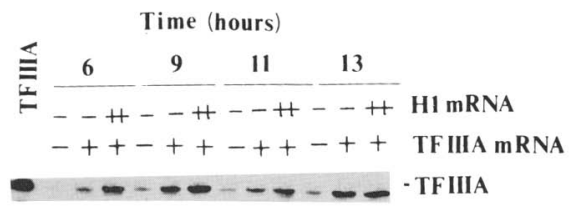

Figure 2. Translation of synthetic HIC and TFIIIA mRNA in developing embryos. Western blot of control and message-injected embryos. Proteins from one embryo equivalent were separated on an $18 \%$ polyacrylamide-SDS gel, transferred to nitrocellulose and probed with specific antibodies against $\mathrm{Hl}$ or $\mathrm{B} 4$, respectively (see Materials and methods). Control $(-)$ and injected $(+,++)$ embryos were taken at the indicated time. $(A)$ Western blot of TFIIIA from control $(-)$ and TFIIIA mRNAinjected $|3 \mathrm{ng},+|$ embryos. Indicated amounts of purified TFIIIA were used as markers. $(B)$ Western blot of $\mathrm{Hl}$ from control $(-)$ and HIC mRNA-injected ( $3 \mathrm{ng}$ ) embryos. The same blot was incubated also with antibody against $\mathrm{B} 4$ protein as an additional control for the amount of loaded protein. $(C)$ The overexpression of $\mathrm{HlC}$ protein does not change the expression of TFIIIA protein. The embryos were injected with TFIIIA mRNA alone or with both TFIIIA mRNA and H1C mRNA $(3 \mathrm{ng},+, 8 \mathrm{ng},++)$. The Western blot with immunopurified antibody against TFIIIA is shown.

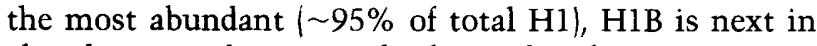
abundance, and HIC is the least abundant in somatic cells (Risley and Eckhardt 1981). We chose to decrease H1A synthesis using ribozymes (see below) because of its abundance. We chose to overexpress $\mathrm{H} 1 \mathrm{C}$, because of the low levels normally present in embryonic chromatin and the capacity to easily monitor an increase in synthesis (see below). Similar data were obtained when histone $\mathrm{Hl}$ variants other than $\mathrm{HIC}$ were overexpressed (not shown). We have not systematically attempted to decrease synthesis of H1B or H1C because they make up $<5 \%$ of total histone $\mathrm{Hl}$ at any time during Xenopus embryogenesis. Genes encoding all of these proteins have been cloned (Old et al. 1982; Perry et al. 1985).

In our first experiments we examined the consequences of increasing histone $\mathrm{HlC}$ synthesis for transcription in Xenopus embryos. Microinjection of in vitro-synthesized histone $\mathrm{HIC}$ mRNA into eggs directed a substantial increase in histone $\mathrm{H} 1 \mathrm{C}$ synthesis through gastrulation (Fig. 2B). In this experiment the abundance of histone $\mathrm{H} 1$ is compared with that of histone $\mathrm{B} 4$, because the amount of total B4 protein in the embryo remains constant through gastrulation (i.e., from fertilization to $14 \mathrm{hr}$ postfertilization; Dworkin-Rastl et al. 1994|. However, because of the rapid increase in the number of embryonic nuclei, the amount of B4 per nucleus decreases during development (Dimitrov et al. 1993). Thus, histone H1 accumulation progressively dilutes the number of nucleosomes containing histone B4 during Xenopus embryogenesis. The newly synthesized histone $\mathrm{H} 1 \mathrm{C}$ is incorporated into embryonic nuclei (Fig. 3) without any obvious effect on the accumulation of small RNAs (Fig. 1, cf. U2, U1, and tRNA; lane 7 with lanes 11 and 12). However, overexpression of histone $\mathrm{H} 1 \mathrm{C}$ does influence the transcription of the oocyte $5 \mathrm{~S}$ rRNA genes (Fig. 1; see Fig. 7, below).
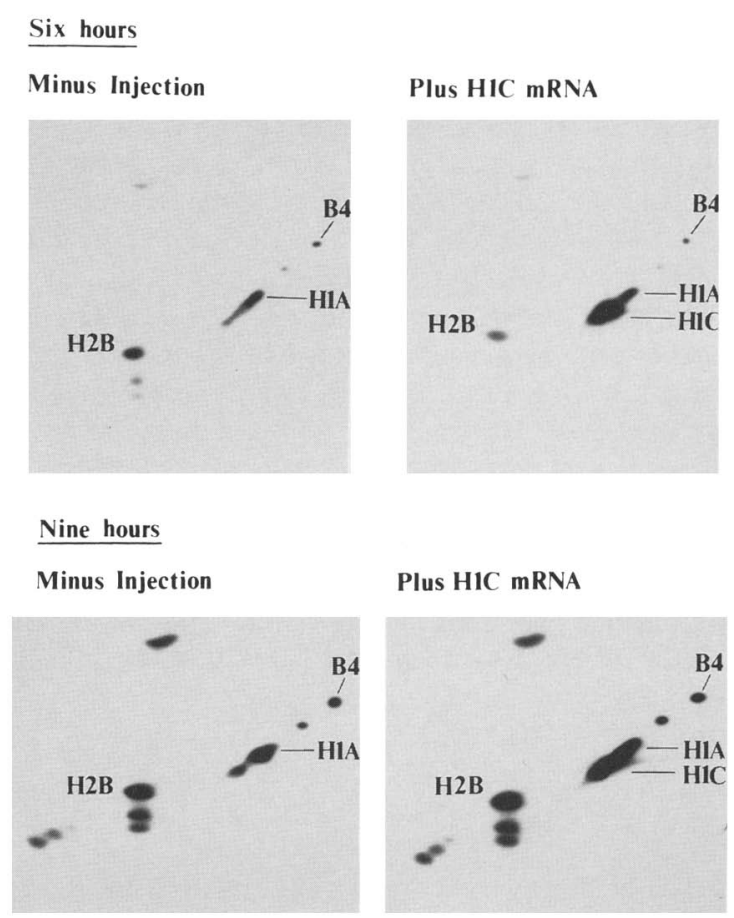

Plus HIC mRNA

Figure 3. Overexpressed histone $\mathrm{HIC}$ is incorporated into chromatin. Two-dimensional electrophoresis of histones isolated from the chromatin of control and $\mathrm{HIC}$ mRNA-injected embryos. Embryos were injected with $3 \mathrm{ng}$ of $\mathrm{HIC} \mathrm{mRNA}$, in 50 $\mathrm{nl}$ of ${ }^{3} \mathrm{H}$-labeled lysine and ${ }^{3} \mathrm{H}$-labeled arginine. Control embryos were injected with tritium-labeled amino acids only. After the indicated time of incubation, nuclei were prepared and histones were isolated by $\mathrm{HCl}$ treatment. Carrier histones from Xenopus erythrocytes were added, and the proteins separated by two-dimensional electrophoresis (Materials and methods). For identification of the tritium-labeled histones, the gels were stained with Coomassie blue to determine the position of unlabeled carrier histones that serve as markers, destained, treated with Amplify, dried, and autoradiographed. (Top panels) Autoradiograph of two-dimensional gel of histones isolated from control (left) and H1C mRNA-injected (right) embryos. Embryos were collected $6 \mathrm{hr}$ after fertilization and histones extracted from them. (Bottom panels) Same as above but for embryos collected $9 \mathrm{hr}$ after fertilization. 
Injection of $\mathrm{HIC}$ mRNA into the egg at the same time as TFIIIA mRNA leads to the selective reduction of oocyte $5 \mathrm{~S}$ rRNA accumulation compared with the activated state in the presence of elevated TFIIIA (Fig. 1, cf. lane 8 with lanes 9 and 10). This decrease in oocyte $5 S$ rRNA gene transcription is at the transcriptional level (data not shown; see Fig. 7, below), indicating that histone $\mathrm{HIC}$ abundance could influence the assembly of transcription complexes on the oocyte 5S rRNA genes in spite of elevated levels of the TFIIIA protein. The failure to activate the oocyte $5 \mathrm{~S}$ rRNA genes is not attributable to any interference by elevated histone $\mathrm{Hl}$ mRNA or $\mathrm{H} 1$ protein on the synthesis of TFIIIA protein (Fig. 2C). This is an important control because it excludes any limitation of translational capacity in the developing embryo (after $\mathrm{Hl}$ mRNA injection) leading to a decrease in TFIIIA synthesis. The constant level of endogenous tRNA gene transcription in the presence of elevated histone H1C protein (see Fig. 7) indicates that histone H1C accumulation does not influence the activity of the other transcription factors (TFIIIC and TFIIIB) required both for tRNA and 5S rRNA gene transcription.

We conclude that a competition exists between the association of TFIIIA, together with the other transcription factors with the oocyte $5 \mathrm{~S}$ rRNA gene (Segall et al. 1980; Setzer and Brown 1985) and the association of histone $\mathrm{Hl}$ with these genes in the chromosome. Therefore, the presence of increased amounts of histone $\mathrm{Hl}$ in chromatin can have a dominant and specific repressive effect on oocyte 5S rRNA gene expression. This effect is dominant because it occurs in the presence of an excess of the transcription factor TFIIIA. Furthermore, because TFIIIA is the limiting transcription factor in the embryo at this time (Brown and Schlissel 1985; Andrews and Brown 1987), histone H1-directed repression of oocyte 5S rRNA gene transcription occurs when TFIIIC and TFIIIB are also in excess.

\section{Elevation of histone H1 levels in vivo does not alter nucleosome structure}

Addition of histone $\mathrm{Hl}$ to in vitro chromatin assembly systems can alter the spacing of the nucleosomal ladder following micrococcal nuclease digestion (RodriguezCampos et al. 1989; Kamakaka et al. 1993). This change in spacing may reflect the incorporation of more than one linker histone molecule per histone octamer into each individual nucleosomal unit (Weintraub 1978). Although the exact structure of such a nucleosomal unit has not been determined, we wished to examine whether unusual nucleosomal structures might be assembled within the Xenopus embryo in response to the presence of additional histone $\mathrm{HIC}$ protein.

We initially repeated the H1C-directed repression of oocyte 5S rRNA gene expression in the presence of excess TFIIIA to confirm the activity of histone HIC by this functional assay (not shown). We then examined the incorporation of newly synthesized histone $\mathrm{HlC}$ into embryonic chromatin at $12 \mathrm{hr}$ postfertilization (Fig. 4A). Microinjection of $\mathrm{HlC}$ mRNA leads to a more than threefold increase (based on densitometry of the twodimensional gel) in the accumulation of total histone $\mathrm{H} 1$ protein within embryonic chromatin, this increase is accounted for by increased accumulation of histone H1C protein. Increased levels of histone $\mathrm{H} 1 \mathrm{C}$ are recovered in fractions containing mononucleosomal particles following injection of histone H1C mRNA into embryos (not shown). This additional histone $\mathrm{Hl}$ protein will conse-
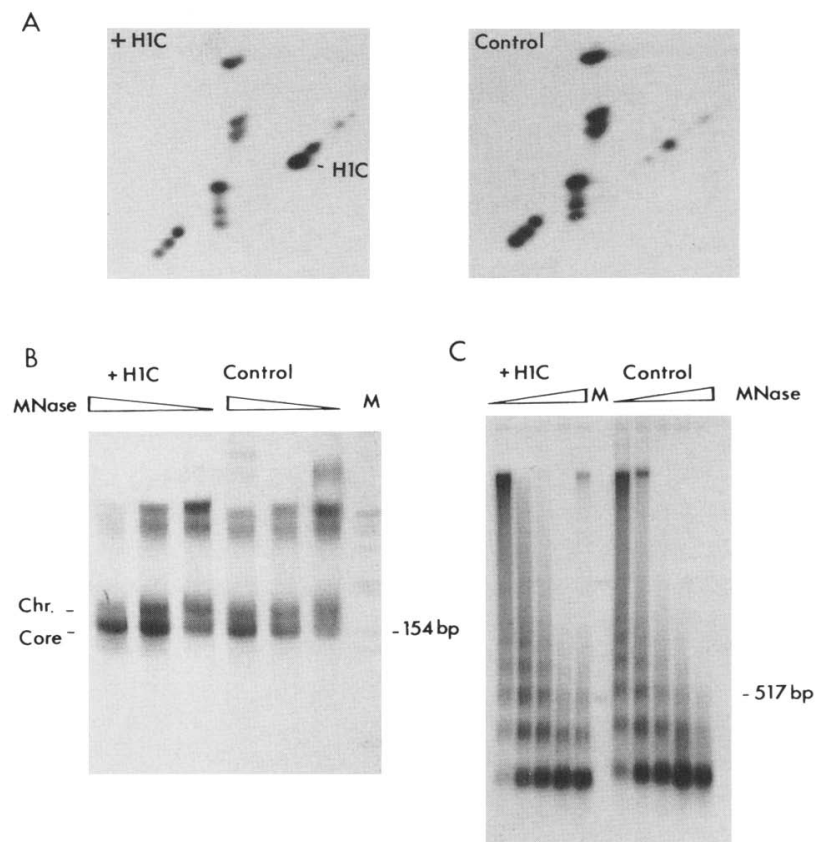

Figure 4. Incorporation of histone $\mathrm{HIC}$ into Xenopus embryonic chromatin does not alter the nucleosomal spacing or the chromatosome organization. $(A)$ Two-dimensional electrophoresis of histones isolated from the chromatin of control and HIC mRNA-injected embryos. Embryos were injected with 8 ng of $\mathrm{HIC}$ mRNA and $3 \mathrm{ng}$ of TFIIIA mRNA, together with 50 $\mathrm{nl}$ of ${ }^{3} \mathrm{H}$-labeled lysine and ${ }^{3} \mathrm{H}$-labeled arginine. Control embryos were injected with tritium-labeled amino acids only. After $12 \mathrm{hr}$ of incubation, nuclei were prepared and histones were isolated by $\mathrm{HCl}$ treatment. Histones were identified as described for Fig. 3. Autoradiographs of histone gels isolated from HIC mRNA-injected (left) and control (right) embryos are shown. HIC is indicated. $(B)$ Micrococcal nuclease digestion patterns of chromatin isolated from control and H1C mRNAinjected embryos $(+\mathrm{HlC})$. As in $A$ except $0.1 \mu \mathrm{Ci}$ of $\left[\alpha^{-32} \mathrm{P}\right] \mathrm{dCTP}$ replaces radiolabeled amino acids. After $12 \mathrm{hr}$ of development, nuclei were isolated from both sets of embryos and their chromatin digested with increasing amounts of micrococcal nuclease $(10,20$, and 50 units from right to left, open wedges). DNA fragments were deproteinized and resolved on a $10 \%$ nondenaturing polyacrylamide gel. An autoradiograph of labeled DNA fragments is shown. A 154-bp marker DNA fragment is indicated as are chromatosome (Chr.) and core particle (Core) length DNA fragments. $(C)$ As in $B$, except $0.5,1,2,5$, and 10 units of micrococcal nuclease are used, respectively, from left to right (open wedges) to digest chromatin from nuclei isolated from control and H1C mRNA-injected embryos. The DNA fragments were deproteinized and resolved on a $1.5 \%$ agarose gel. An autoradiograph of labeled DNA fragments is shown. A 517-bp marker DNA fragment is indicated. 
quently dilute the number of nucleosomes containing the linker histone B4 (Dimitrov et al. 1993). It is important to note that all of the histone HIC protein may not be incorporated into individual nucleosomal particles, rather like transcription factors may interact with DNA both specifically or nonspecifically (Lin and Riggs 1975). Although histone $\mathrm{Hl}$ protein binds preferentially to DNA wrapped around the core histones rather than to naked DNA (Hayes and Wolffe 1993), under physiological ionic conditions histone $\mathrm{H} 1$ is readily exchanged between DNA that is either naked or wrapped around the core histones within a nucleosome (Thomas and Rees 1983; van Holde 1989). Nevertheless, increase in total $\mathrm{H} 1$ protein concentration will influence the equilibrium binding of histone $\mathrm{Hl}$ protein within the nucleosome (Hayes and Wolffe 1993). Under our experimental conditions in which the histone $\mathrm{Hl}$ protein content of chromatin is elevated in vivo, no increase in nucleosomal repeat is observed following micrococcal nuclease digestion (Fig. 4B,C). Moreover, the proportional protection of chromatosome $(\sim 166 \mathrm{bp})$ length compared with core particle $(\sim 146 \mathrm{bp})$ length DNA fragments appears unchanged in the presence or absence of additional histone $\mathrm{H} 1$ during extended micrococcal nuclease digestion (Fig. 4B). We conclude that elevated histone $\mathrm{Hl}$ is not perturbing the normal chromatin structure within the $\mathrm{Xe}$ nopus embryo.

\section{Ribozyme-mediated reduction in histone $H 1$ gene expression during Xenopus embryogenesis: consequences for $5 S$ rRNA accumulation}

Ribozymes provide an attractive approach for the elimination of the expression of particular genes in vivo /Cotten and Birnsteil 1989|. We have made use of a ribozyme approach to examine the consequences of a severe reduction in the accumulation of the major variant of histone $\mathrm{H} 1$ (H1A) for RNA accumulation in general and for the 5S rRNA genes in particular. A hammerhead ribozyme (Haseloff and Gerlach 1988) flanked by sequences homologous to H1A mRNA was introduced into a X. laevis tyrosine tRNA intron (Stutz et al. 1989). Following injection into a fertilized Xenopus egg, this ribozyme effectively restricts the accumulation of $\mathrm{HlA}$ protein in the Xenopus embryo (Kandolf 1992; see Materials and methods). Injection of the HlA ribozyme into the Xenopus egg leads to a four- to fivefold reduction in the accumulation of total histone $\mathrm{Hl}$ within the embryo by the beginning of gastrulation (Fig. 5A, $9 \mathrm{hr}$, measured by densitometric analysis of the autoradiograph|. H1A is normally the predominant variant $(\sim 95 \%$ of total $\mathrm{Hl}$ protein) at this embryonic stage (Fig. 3). Moreover, because histone H1A mRNA normally comprises $\sim 95 \%$ of total $\mathrm{Hl}$ mRNA at this stage (i.e., $\mathrm{H} 1 \mathrm{~A}+\mathrm{H} 1 \mathrm{~B}+\mathrm{H} 1 \mathrm{C}$; P. Bouvet, unpubl.|, this four- to fivefold reduction of $\mathrm{Hl}$ protein synthesis is more severe than the two- to threefold reduction in H1A mRNA levels (Fig. 5B). Thus, it is possible that the HlA ribozyme both cleaves H1A mRNA and restricts synthesis of the protein through the formation of RNA duplexes that arrest the translation process
A Time (hours)

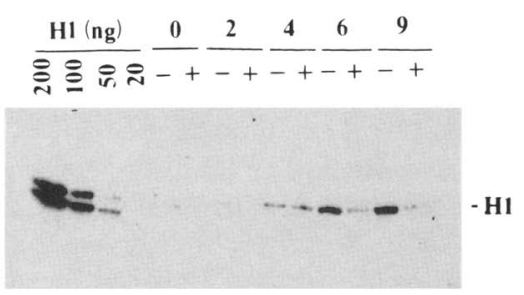

B

Time (hours)

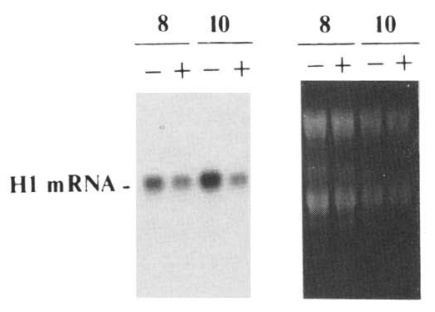

C

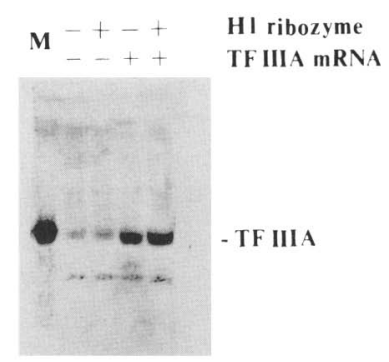

Figure 5. Injection of ribozyme in Xenopus embryos selectively inhibits the synthesis of histone $\mathrm{H} 1$. $\{A \mid$ Western blot of control and HlA ribozyme-injected embryos. HCl-extracted proteins from one equivalent embryo were separated on $18 \%$ polyacrylamide-SDS gel, transferred to nitrocellulose, and reacted with immunopurified antibody to Xenopus H1. Control $(-)$ and HlA ribozyme-injected $(10 \mathrm{ng},+)$ embryos were taken at the indicated time. Linker histones purified from Xenopus erythrocytes are used as a control. $(B)$ Northern analysis of control and ribozyme-injected embryos. Total RNAs from one equivalent embryo were subjected to Northern blot hybridization with a ${ }^{32}$ P-labeled H1A-specific gene probe (Perry et al. 1985). Control $(-)$ and H1A ribozyme-injected $(+)$ embryos were taken at the indicated times. $(C)$ Western blot of TFIIIA protein levels in control and ribozyme injected embryos at $9 \mathrm{hr}$ of development. Embryos were either injected with TFIIIA mRNA $(3 \mathrm{ng})$ alone, with TFIIIA mRNA plus the $\mathrm{Hl}$ A ribozyme $(10 \mathrm{ng})$, with ribozyme alone, or not injected. At $9 \mathrm{hr}$ postfertilization, proteins from one equivalent embryo were separated on a $10 \%$ polyacrylamide-SDS gel, transferred to nitrocellulose, and reacted with immunopurified antibody to Xenopus TFIIIA. TFIIIA purified from Xenopus oocytes was used as a control, $M$ (Smith et al. 1984).

(hybrid arrest of translation). It is also possible that the fraction of mRNA accessible to the ribozyme is limited through association of the $\mathrm{Hl}$ mRNA with the translationally repressive masking proteins in the embryo (Tafuri and Wolffe 1993). An additional control determined that expression of the ribozyme had no influence on the abundance of TFIIIA protein in the embryo in the 
presence or absence of microinjected TFIIIA mRNA (Fig. $5 \mathrm{Cl}$. Furthermore, the ribozyme does not influence the apparent activity of the other class III gene transcription factors TFIIIB and TFIIIC, because endogenous tRNA gene transcription is unaffected when the ribozyme is injected into the developing embryo (see Fig. 7, below). Cloned class III genes requiring TFIIIB and TFIIIC are also transcribed equivalently in extracts prepared from control and ribozyme-treated embryos (not shown).

We examined the influence of reducing histone H1A synthesis during early embryogenesis on oocyte and somatic 5S rRNA gene expression (Fig. 6A, cf. lanes 1 and 2). This reduction in histone HlA synthesis has no major effect on the relative accumulation of oocyte and somatic 5S rRNA through early gastrulation (Fig. 6, cf. lanes 1 and 2). The approximately equivalent accumulation of somatic 5S rRNA and oocyte 5S rRNA reflects a 50:1 preference for expression of the somatic 5S rRNA gene at $12 \mathrm{hr}$ postfertilization, even when histone H1A synthesis is reduced. A 50:1 transcriptional preference is observed when naked DNA templates encoding oocyte and somatic 5S rRNA genes are transcribed in egg extracts (Wolffe and Brown 1987). Thus, observing this differential expression probably reflects the major contribution transcription factor limitation makes to differential 5S rRNA gene regulation during the early stages of Xenopus embryogenesis (see Discussion). However, more sensitive RNase protection assays reveal changes in the transcription of the oocyte 5S RNA genes by $15 \mathrm{hr}$ in development when histone H1A synthesis is impaired (see Fig. 7, below). Thus, the influence of reduced histone $\mathrm{Hl}$ synthesis may predominate later in gastrulation, it is at this time that $\mathrm{H} 1$ normally replaces $\mathrm{B} 4$ almost completely within embryonic chromatin (Dimitrov et al. 1993).

We then asked whether the reduction of histone $\mathrm{H} 1$ in early embryonic chromatin would have consequences for the activation of oocyte $5 \mathrm{~S}$ rRNA gene expression in the presence of excess TFIIIA. Injection of TFIIIA mRNA leading to an elevation of TFIIIA concentration of approximately four- to fivefold (not shown) leads to a more substantial activation of oocyte 5S rRNA gene transcription (twofold) from histone H1-deficient chromatin (Fig. $6 \mathrm{~B}$ ), than from chromatin containing the normal mixture of histone $\mathrm{H} 1$ and B4 (Fig. 6, cf. lanes 3 and 4, and 7 and 8). Thus, embryonic chromatin deficient in histone $\mathrm{H} 1$ is more accessible to transcription factors.

These results suggest that the abundance of histone $\mathrm{Hl}$ in early embryonic chromatin will only influence the differential expression of the oocyte and somatic $5 \mathrm{~S}$ rRNA genes beyond the level of differential expression (i.e., the 50-fold somatic preference) established through the differential interaction of transcription factors with the genes as naked DNA (Wolffe and Brown 1987).

The influence of increase or reduction in histone H1C accumulation during normal Xenopus embryogenesis on $5 S$ rRNA gene transcription

Our experiments so far have established that an increase

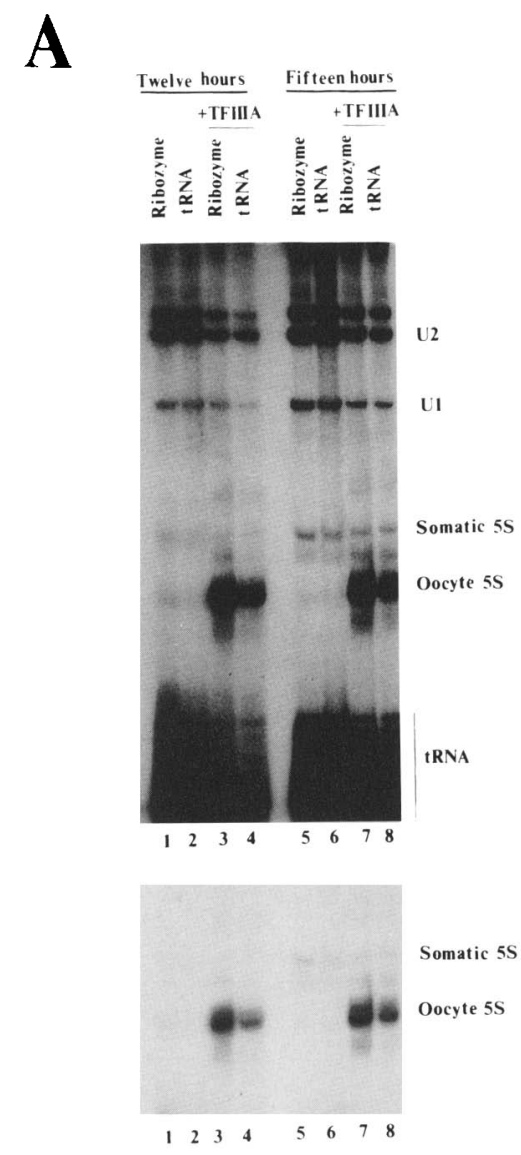

\begin{tabular}{|c|c|c|c|c|}
\hline & \multirow[b]{2}{*}{ Ribozyme } & \multirow[b]{2}{*}{ tRNA } & \multicolumn{2}{|c|}{+ TFIIIA } \\
\hline & & & Ribozyme & tRNA \\
\hline U1 & 7.7 & 6.4 & 5.2 & 4.8 \\
\hline Somatic $5 \mathrm{~S}$ & 4.1 & 3.7 & 4.2 & 3.0 \\
\hline Oocyte $5 \$$ & - & - & 75.0 & 37.0 \\
\hline
\end{tabular}

Figure 6. Effects of histone H1A depletion on oocyte 5S rRNA gene expression. $(A)$ Control embryos were injected with $10 \mathrm{ng}$ of tyrosine tRNA alone (lanes 2,6) or together with $3 \mathrm{ng}$ of TFIIIA mRNA (lanes 4,8). Other embryos were injected with 10 $\mathrm{ng}$ of $\mathrm{H} 1 \mathrm{~A}$ ribozyme alone (lanes 1,5) or together with $3 \mathrm{ng}$ of TFIIIA mRNA (lanes 3,7). All embryos were coinjected with 0.1 $\mu \mathrm{Ci}$ of $\left[\alpha^{-32} \mathrm{P}\right]$. After the indicated time, total RNAs were extracted and the RNA of one equivalent embryo was separated on a semidenaturing gel for $24 \mathrm{hr}$ at $10 \mathrm{~mA}$. (Bottom panel) A shorter exposure of top panel. The positions of U2, U1, somatic $5 S$, oocyte $5 S$ and tRNAs are indicated. $(B)$ Quantitation by scanning densitometry of the $15 \mathrm{hr}$ results shown in $A$ (lanes 5-8). Absolute values (arbitrary units) are shown for Ul, somatic 5S, and oocyte $5 \mathrm{~S}$ rRNA. The oocyte $5 \mathrm{~S}$ rRNA values in the absence of microinjected TFIIIA mRNA were not significantly above background on the autoradiograph used for this densitometric analysis.

in histone $\mathrm{HIC}$ protein early in Xenopus embryogenesis will repress oocyte $5 S$ rRNA gene expression under con- 
A

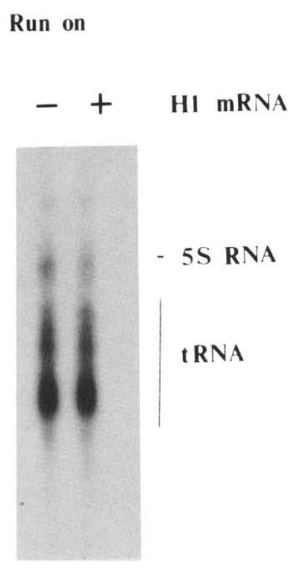

RNase Prot.

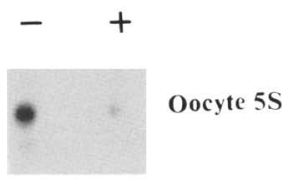

B

Run on

HI ribozyme

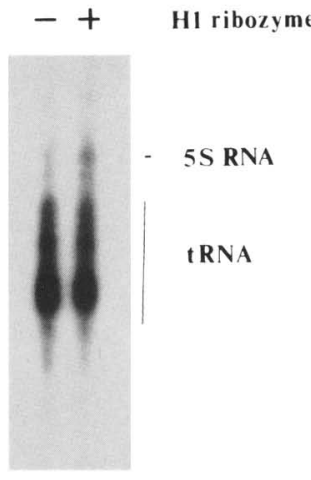

RNase Prot.

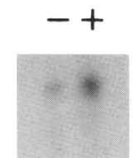

Oocyte 5 S

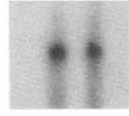

Somatic $5 S$
Immunoblot

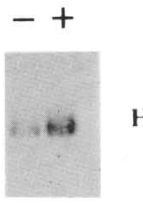

H 1 tively represses oocyte $5 S$ rRNA gene transcription. Embryos were either not injected $(-)$ or injected (+) with H1C mRNA (8 $\mathrm{ng}$ ). After $9 \mathrm{hr}$ postfertilization, nuclei were fractionated from both sets of embryos and run-on transcription allowed in the presence of radioactive precursors (Materials and methods). RNAs synthesized under these conditions are shown resolved on a $10 \%$ denaturing polyacrylamide gel (Run on). In a parallel reaction, radiolabeled RNAs synthesized by run-on RNAs were hybridized to an excess of antisense RNA corresponding to oocyte or somatic $5 \mathrm{~S}$ rRNA, followed by digestion with RNase (Materials and methods). Protected RNAs corresponding to oocyte or somatic $5 \mathrm{~S}$ rRNA are shown. Finally, histone $\mathrm{Hl}$ protein present in the control and injected embryonic nuclei is shown by immunoblotting (Immunoblot). (B) Inhibition of histone

${ }^{\mathrm{H} 1} \mathrm{H} 1 \mathrm{~A}$ synthesis through $15 \mathrm{hr}$ postfertilization selectively facilitates oocyte $5 S$ rRNA gene expression. As in $A$, except embryos were either not injected $(-)$ or injected with the H1A ribozyme ( $10 \mathrm{ng}$ ). After $15 \mathrm{hr}$ postfertilization, the abundance of histone $\mathrm{Hl}$ in nuclei (Immunoblot), the transcriptional properties of the nuclei (Run on), and the relative transcription of oocyte, and somatic 5S rRNA (RNase Prot.) were assayed. ditions of TFIIIA excess (Fig. 1). We have also determined that normal histone HlA expression is not essential for a substantial part of differential oocyte and somatic $5 \mathrm{~S}$ rRNA gene expression (Fig. 6). Thus, in principle, both TFIIIA limitation and histone $\mathrm{H} 1$ accumulation may have a role in $5 S$ rRNA gene regulation during development. Nevertheless, we have not established that altering histone $\mathrm{H} 1$ levels will influence differential 5S rRNA gene expression during development in the absence of excess TFIIIA. These experiments require a more sensitive combination of assays because specific oocyte $5 \mathrm{~S}$ rRNA and somatic $5 S$ rRNA gene transcription must be examined under conditions where 5S rRNA gene transcription is already substantially reduced attributable to TFIIIA limitation (Figs. 1, 2, and 6).

First, we overexpressed histone $\mathrm{H} 1 \mathrm{C}$ through injection of H1C mRNA without injection of TFIIIA mRNA. Synthesis of $\mathrm{H} 1 \mathrm{C}$ by early gastrulation $(9 \mathrm{hr}$ postfertilization) is substantially elevated (Fig. 7A, Immunoblot). Run-on transcription from chromatin isolated at this time (Fig. 7A, Run on) shows that total 5S rRNA gene transcription is reduced under conditions where $\mathrm{HlC}$ protein is elevated. RNase protection experiments (Fig.
7A, RNase Prot) show that the reduction in total $5 \mathrm{~S}$ rRNA gene transcription can be specifically attributed to a reduction in transcription of the oocyte 5S rRNA genes. Somatic 5S rRNA gene transcription is unaffected. Control RNase protection assays also indicated that tRNA transcription was unaffected by overexpression of H1C. We conclude that overexpression of histone H1C protein during normal development will specifically inhibit oocyte 5S rRNA gene transcription.

Second, we reduced histone H1A expression through injection of the ribozyme without injection of TFIIIA mRNA. Synthesis of H1A through gastrulation $(15 \mathrm{hr}$ postfertilization) remains substantially reduced (Fig. 7B, Immunoblot). Run-on transcription from chromatin isolated at this time (Fig. 7B, Run on) shows that total 5S rRNA gene transcription is increased under conditions where H1A protein is reduced. RNase protection experiments (Fig. 7B, RNase Prot.) show that the elevation of total $5 \mathrm{~S}$ rRNA gene transcription can be specifically attributed to an increase in transcription of the oocyte $5 \mathrm{~S}$ rRNA genes. We conclude that reduction of histone HlA protein will specifically facilitate oocyte $5 S$ rRNA gene transcription. Thus, alterations in histone $\mathrm{Hl}$ levels will 
influence differential $5 S$ rRNA gene expression in the presence of normal levels of TFIIIA protein within the embryo.

\section{Discussion}

The regulation of the chromosomal oocyte $5 \mathrm{~S}$ rRNA genes during Xenopus embryogenesis depends on the abundance of TFIIIA and on the incorporation of histone $\mathrm{H} 1$ into chromatin (Figs. 1 and 7). TFIIIA specifically activates and histone $\mathrm{Hl}$ specifically represses oocyte $5 \mathrm{~S}$ rRNA gene transcription (Fig. 8). We suggest that the developmentally regulated expression of linker histones, in which the cleavage stage linker histone B4 is diluted within chromatin by histone $\mathrm{H} 1$ during Xenopus embryogenesis (Dimitrov et al. 1993), will have specific consequences for how the transcriptional machinery utilizes a chromatin template. Moreover, our results demonstrate that histones can exert dominant repressive effects on transcription both in the presence of an excess of transcription factors (Fig. 1) and during normal development (Fig. 7).

\section{Histone $H 1$ and the selective repression of the oocyte $5 S$ rRNA genes}

The roles of individual histones and their modifications in vitro in mediating general transcriptional repression have been defined using the Xenopus 5S RNA genes (Shimamura et al. 1988, 1989; Tremethick et al. 1990; Almouzni et al. 1990, 1991; Clark and Wolffe 1991; Hayes and Wolffe 1992; Lee et al. 1993). Histones and transcription factors were found to compete for association with the 5S rRNA gene, yet the first histones to associate with the 5S rRNA genes during chromatin assembly were less repressive toward transcription. Chromatin assembly in

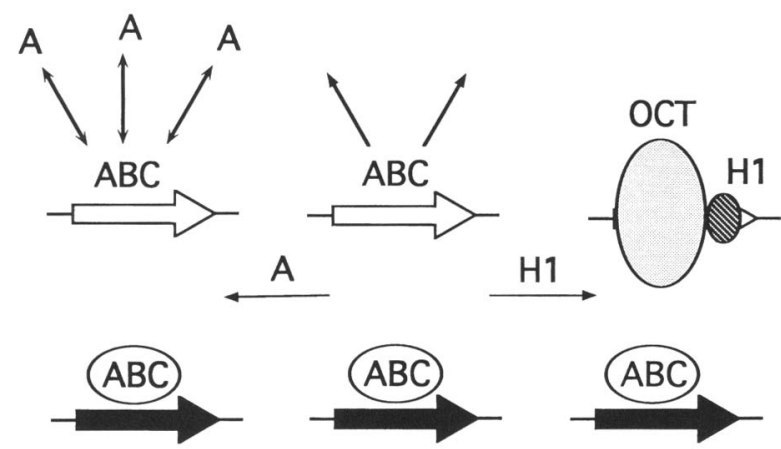

Figure 8. Model for differential oocyte and somatic 5S rRNA gene expression. The somatic 5S rRNA gene (solid arrow) and oocyte 5S rRNA gene (open arrow) are shown associated with transcription factors TFIIIA, TFIIIB, and TFIIIC. The somatic transcription complex is stable as indicated by the ellipsoid around it; the oocyte transcription complex is unstable indicated by the arrows. Additional TFIIIA promotes oocyte tran scription complex retention; additional histone $\mathrm{H} 1$ promotes oocyte transcription complex displacement through nucleosome formation. vivo and in vitro is optimally coupled to replication (Worcel et al. 1978; Almouzni et al. 1991; Gruss et al. $1990)$ such that an acetylated histone tetramer $(\mathrm{H} 3 / \mathrm{H} 4)_{2}$ is sequestered before $\mathrm{H} 2 \mathrm{~A} / \mathrm{H} 2 \mathrm{~B}$ and, finally, $\mathrm{H} 1$. This creates a window of opportunity for the programming of the 5S rRNA genes with transcription factors, because the $(\mathrm{H} 3 / \mathrm{H} 4)_{2}$ tetramer is less repressive than the complete $(\mathrm{H} 2 \mathrm{~A} / \mathrm{H} 2 \mathrm{~B}, \mathrm{H} 3 / \mathrm{H} 4)_{2}$ octamer, whereas chromatin containing histone $\mathrm{Hl}$ is essentially inert and inaccessible to the class III gene transcriptional machinery. If the transcription factors bind stably to DNA before nucleosome assembly is complete a gene is potentially active. However, if they do not they are subject to displacement attributable to competing histone-DNA interactions (for review, see Wolffe 1992). Thus, the somatic 5S rRNA genes that rapidly form a stable complex with transcription factors TFIIIA and TFIIIC (Lassar et al. 1983; Wolffe 1988; Keller et al. 1992; Siedel and Peck 1992) might resist competing histone-DNA interactions, whereas the oocyte 5S rRNA genes that do not rapidly form a stable complex with these same transcription factors will be open to repression.

Consistent with this hypothesis, increasing the level of transcription factor TFIIIA in egg extracts will selectively activate the oocyte 5S rRNA genes (Wolffe and Brown 1987; Wolffe 1989a). Likewise elevating TFIIIA levels in developing embryos will selectively activate oocyte 5S rRNA gene expression (Figs. 1, 6, and 7; Brown and Schlissel 1985; Andrews and Brown 1987). Thus, limitation of transcription factors plays a key role in the inactivation of the oocyte $5 \mathrm{~S}$ rRNA genes. Importantly, the oocyte $5 S$ rRNA genes are inactive but are not repressed under these conditions, because addition of transcription factors activates their transcription.

Evidence for a competing histone-DNA interaction influencing the association of transcription factors with the oocyte $5 \mathrm{~S}$ rRNA genes came initially from in vitro experiments. The key protein believed to be important in repressing the oocyte $5 \mathrm{~S}$ rRNA genes is histone $\mathrm{H} 1$ (Schlissel and Brown 1984). Removal of histone $\mathrm{Hl}$ from somatic cell chromatin allows transcription factors to gain access to the oocyte type $5 \mathrm{~S}$ rRNA genes. The oocyte $5 S$ rRNA genes in somatic cells in vivo are known to be packaged into nucleosomes (Gottesfeld and Bloomer 1980; Young and Carroll 1983) and the positioning of histone-DNA contacts appears dependent on histone $\mathrm{H} 1$ (Chipev and Wolffe 1992). Sliding of nucleosomes following $\mathrm{H} 1$ removal may allow transcription factors access to the oocyte $5 \mathrm{~S}$ rRNA genes. The addition of histone $\mathrm{Hl}$ to chromatin deficient in the protein in vitro can cause the selective repression of oocyte $5 \mathrm{~S}$ rRNA genes and the displacement of transcription factors (Wolffe 1989b; Chipev and Wolffe 1992).

We have now determined that histone $\mathrm{Hl}$ will direct the selective repression of the oocyte 5S RNA genes in vivo (Figs. 1 and 7). This establishes for the first time in a metazoan that the regulated expression of a specific histone can influence the expression of a specific gene. Importantly, histone $\mathrm{H1C}$ association with chromatin (Figs. 3 and 4) has a dominant-repressive effect on the 
transcription of the oocyte 5S RNA genes in spite of a continued excess of transcription factor TFIIIA (Fig. 2C).

Histone $\mathrm{Hl}$ prefers the prior assembly of histone octamers onto DNA for efficient incorporation into chromatin (Hayes and Wolffe 1993) and will direct the formation of nucleosomal arrays on the oocyte 5S rRNA genes (Chipev and Wolffe 1992). Association of histone octamers with the oocyte 5S rRNA genes are necessary for the selective repression of oocyte $5 \mathrm{~S}$ rRNA genes within genomic DNA in vitro (Wolffe 1989b). In our assays accumulation of an excess of histone $\mathrm{H} 1$ does not alter the physiological features of chromatin attributed to the presence of linker histones, including the presence of a normal chromatosome stop (Simpson 1978), and nucleosome spacing as revealed by digestion with micrococcal nuclease (Fig. 6). This suggests that the increase in histone $\mathrm{Hl}$ is not leading to the general formation of different nucleosomal structures (Weintraub 1978) but is, instead, leading to a more stable equilibrium association of histone $\mathrm{Hl}$ with nucleosomal DNA and to a more efficient replacement of histone $\mathrm{B} 4$ by histone $\mathrm{Hl}$ in the nucleosomes of embryonic chromatin. We suggest that either $\mathrm{Hl}$ association with the octamer or the folding of the nucleosomal array dependent on histone $\mathrm{Hl}$ may direct the dissociation of TFIIIA and other weakly associated transcription factors from the oocyte $5 \mathrm{~S}$ rRNA genes. These same transcription factors are stably associated with the somatic 5S rRNA gene and, hence, cannot be displaced by the sequestration of histone $\mathrm{Hl}$ (Fig. 7). Another contributory factor in the selective repression of oocyte 5S rRNA genes by histone $\mathrm{Hl}$ might be the preference of $\mathrm{Hl}$ for AT-rich DNA (Renz and Day 1976; Jerzmanowski and Cole 1990). The oocyte 5S rRNA genes all have AT-rich spacers while those of the somatic genes are GC rich, which may lead $\mathrm{Hl}$ to associate preferentially with the oocyte genes (Schlissel and Brown 1984). Maintenance of the final repressed state is likely to be a local effect of histone-DNA interactions because the developmental inactivity of the oocyte $5 \mathrm{~S}$ rRNA genes persists when the chromosomes are cleaved by restriction enzymes between the genes /Gurdon et al. 1982).

\section{Gene expression in H1-deficient embryos}

Substantial experimental evidence supports the hypothesis that the limitation of transcription factor activity in the early embryo is a major component of the differential expression of the oocyte and somatic 5S rRNA genes (Andrews and Brown 1987; Wolffe and Brown 1987; Rollins et al. 1993). This limitation leads to at least a 50-fold preference for transcription of a somatic over an oocyte 5S rRNA gene on naked DNA (Wolffe and Brown 1987). Because there are 50 times more oocyte 5S rRNA genes than somatic 5S rRNA genes, this would lead to equivalent accumulation of oocyte versus somatic 5S rRNA. Thus, it is not surprising that reduction in histone $\mathrm{Hl}$ content within chromatin does not influence the relative expression of the oocyte and somatic $5 \mathrm{~S}$ rRNA genes substantially beyond this 50 -fold ratio especially at early times of embryogenesis when chromatin is still relatively deficient in histone H1 (Dimitrov et al. 1993; Fig. 6). However the histone H1-deficient chromatin is more easily programmed with transcription factors (Fig. 6). More importantly, sensitive RNase protection assays using transcripts generated directly from embryonic chromatin at $15 \mathrm{hr}$ postfertilization (Fig. 7) reveals that oocyte 5S rRNA gene expression is facilitated at physiologic transcription factor levels by a reduction in the content of histone $\mathrm{H} 1$ protein. TFIIIA activation of transcription is therefore more vigorous within the histone H1-deficient chromatin later in development $(15 \mathrm{hr}$ postfertilization) when histone $\mathrm{H} 1$ would have normally substantially replaced histone B4 in chromatin (Dimitrov et al. 1993). The cleavage linker histone B4 is much more acidic in the carboxy-terminal tail than histone $\mathrm{Hl}$ (Smith et al. 1988; Dimitrov et al. 1993); hence, like phosphorylated histone $\mathrm{H1}$, it might be expected to have a weaker interaction with DNA (Jerzmanowski and Cole 1990). Thus, B4 may not compete effectively with transcription factors for association with the oocyte $5 \mathrm{~S}$ rRNA genes. This suggests that specific linker histone variants may exert selective effects on the transcription of the chromatin template with which they are associated.

At the MBT, during Xenopus embryogenesis, there is a general activation of transcription of many genes, including the oocyte 5S RNA genes (Newport and Kirschner 1982a,b; Wakefield and Gurdon 1983; Wormington and Brown 1983; Andrews and Brown 1987; Rupp and Weintraub 1991). We find that normal levels of histone $\mathrm{Hl}$ in chromatin are not necessary for the activation of transcription at the MBT (Fig. 6). Thus, a reduction in histone $\mathrm{Hl}$ does not appear to favor or disfavor expression of U1, U2, somatic $5 \mathrm{~S}$, or the bulk of the tRNA genes. The only genes that we have so far detected whose transcription is influenced by $\mathrm{Hl}$ protein are the oocyte 5S rRNA genes. The oocyte 5S rRNA genes are normally activated at the MBT and are subsequently repressed as gastrulation proceeds (Andrews et al. 1991; Rupp and Weintraub 1991). This transition correlates with the accumulation of levels of histone $\mathrm{Hl}$ in the embryo that are stoichiometric with the core histones (Dimitrov et al. 1993). Because increasing levels of histone $\mathrm{H} 1$ in the MBT embryo will direct the specific repression of oocyte 5S rRNA gene transcription before gastrulation is complete (Figs. 1 and 7), we suggest that the transient nature of oocyte 5S rRNA gene activation following expression of TFIIIA in the cleavage-stage embryo is probably attributable to accumulation of endogenous histone $\mathrm{Hl}$ toward the end of gastrulation (Andrews and Brown 1987). It will be of interest to examine whether the transcription of other genes transiently activated at the MBT (Rupp and Weintraub 1991) will be repressed in a comparable H1-dependent way. Significant changes in the utilization of regulatory elements for transcription occur during early mammalian development (Martinez-Salas et al. 1989; Majumder et al. 1993). Our results indicate that these events may also be related to transitions in linker histone expression during 
the first cleavage events following fertilization (Clark et al. 1992).

\section{Materials and methods}

\section{Plasmid constructions}

The coding region of $\mathrm{HlC}$ (Old et al. 1982) was cloned by PCR from $X$. laevis genomic DNA using the primers $5^{\prime}$-GAATTT. AAGCTTCAAAGATGACAG-3' and 5'-GGAACTCTAGAGTTACTTTTTAGC- $3^{\prime}$. This fragment was then subcloned into the $\mathrm{XbaI}$ and HindIII sites of pSP64pA (Promega). The coding region of TFIIIA RNA was subcloned from pSPTF15 (Andrews and Brown 1987) into the XbaI and HindIII sites of pSP64pA. pSP5Soo was constructed by subcloning a 195-bp fragment excised by BamHI from pXlo316 (Wormington et al. 1981), containing the $X$. laevis major oocyte 5S rRNA gene, into pSP72 (Promega).

The construction of H1A ribozyme was performed according to Kandolf (1992). A hammerhead ribozyme (Haseloff and Gerlach 1988) was introduced into the intron of the Xenopus tyrosine tRNA (Stutz et al. 1989). The tyrosine tRNA was cloned by PCR from genomic DNA using the primers 5'-GCCCAAGCTTAACAATTGAAG-3' and 5'-GCGGGATCCTCATCTCCTTC- $3^{\prime}$. The 188 -bp fragment was subcloned into the BamHI and HindIII sites of pSP72 (Promega). An ApaI site was introduced into the tRNA intron (Cotten and Birnstiel 1989). The histone H1A complementary sequence (Perry et al. 1985) was then introduced in this Apal site using these oligonucleotides: $5^{\prime}$-CTTTTTAGCGgctgatgagtccgtgaggacgaaaCTCTTGGTGGCGGGCC-3' and the opposite strand 5'-CGCCACCAAGAGtttcgtcctcacggactcatcagcCGCTAAAAAGGGCC-3'. The ribozyme sequence is in lowercase letters; $\mathrm{H} 1 \mathrm{~A}$ sequences are in uppercase. All the constructions were confirmed by sequencing.

\section{Microinjection of embryos and RNA analysis}

In vitro transcription reactions were performed as described by Krieg and Melton (1984) using linearized plasmids. To synthesize a $5^{\prime}$-terminal capped mRNA, $0.5 \mathrm{mM} \mathrm{M}^{7} \mathrm{G}\left(5^{\prime}\right) \mathrm{ppp}\left(5^{\prime}\right) \mathrm{Gm}$ was introduced in the reaction. The in vitro-synthesized mRNA was extracted with 1:1 phenol/chlorofom and then ethanol precipitated in the presence of $2.0 \mathrm{M}$ ammonium acetate.

Xenopus eggs were fertilized in vitro and maintained in water. Fertilized eggs were dejellied with $2 \%$ cysteine $(\mathrm{pH} 8.0)$ and injected during the first cleavage. Embryos were maintained in $0.1 \times \mathrm{OR} 2 / 5 \%$ Ficoll for $2-3 \mathrm{hr}$ before being transferred to water. About $30 \mathrm{nl}$ of solution containing the various mRNAs (for details, see figure legends $\mid$ and $0.1 \mu \mathrm{Ci}$ of $\left[\alpha^{-32} \mathrm{P} \mid \mathrm{GTP}\right.$ were injected into each embryo. Embryos were allowed to develop at $22^{\circ} \mathrm{C}$ to the appropriate stage, and RNA was then extracted as described by Harland and Misher (1988). The radiolabeled RNAs were separated on a semidenaturing gel according to Wakefield and Gurdon (1983) to separate the 5S oocyte-type RNA from the somatic 5S RNA ( $15 \%$ acrylamide, $4 \mathrm{M}$ urea, $1 \times$ TBE gels were run in $1 \times$ TBE for $24 \mathrm{hr}$ at $10 \mathrm{~mA}$. Gels were fixed for $30 \mathrm{~min}$ in $10 \%$ acetic acid, $10 \%$ methanol, before drying). Quantitation of labeled RNAs was by laser densitometric analysis of autoradiographs using a Molecular Dynamics densitometer.

\section{Preparation of nuclei and isolation of proteins}

Embryos were thawed in ice, and nuclei were isolated as described (Wolffe 1989b). Histones and the protein B4 were extracted from nuclei by overnight treatment with $0.25 \mathrm{~N} \mathrm{HCl}$, followed by precipitation with $80 \%$ TCA to a final concentra- tion of $20 \%$ (Dimitrov et al. 1993). After centrifugation the pellets were washed twice with acetone containing $0.2 \% \mathrm{HCl}$, followed by one wash with acetone only, and dried.

Total proteins from embryos were prepared by homogenizing the embryos in $1.0 \mathrm{M}$ Tris- $\mathrm{Hcl}(\mathrm{pH} 8.9), 2 \%$ SDS, and $1 \%$ dithiothreitol (Andrews and Brown 1987), followed by centrifugation for $15 \mathrm{~min}$ at $4^{\circ} \mathrm{C}$ in a top bench centrifuge. The supernatant was used for further analysis by SDS-polyacrylamide electrophoresis (see below).

\section{Transcription extract and in vitro transcription} of embryonic chromatin

Run-on transcription of Xenopus embryonic chromatin was as described (Wolffe 1989b). Briefly, 50 injected embryos at midblastula transition were washed twice in ice-cold extraction buffer (50 mM HEPES-KOH at $\mathrm{pH} 7.5 ; 50 \mathrm{~mm} \mathrm{KCl}, 5 \mathrm{~mm} \mathrm{MgCl}_{2}$, $2 \mathrm{mM} \beta$-mercaptoethanol). Embryos were placed in $0.65-\mathrm{ml} \mathrm{mi-}$ crotubes, and excess buffer removed and centrifuged at $4^{\circ} \mathrm{C}$ at $9000 \mathrm{~g}$ for $10 \mathrm{~min}$. The cytoplasmic layer that contains endogenous chromatin was removed carefully. Radiolabeled ribonucleoside triphosphate $\left[\alpha^{-32} \mathrm{P}\right] \mathrm{GTP}$ and $0.5 \mathrm{mM}$ ATP, UTP, and CTP were added, and run-on transcription allowed.

Transcription reactions with oocyte nuclear extract and plasmid pXP10 (Wolffe et al. 1986) were as described by Wolffe and Brown (1987). Transcription reaction products were dissolved in $90 \%$ formamide and analyzed on a $6 \%$ acrylamide $8 \mathrm{M}$ urea gel.

\section{RNase protection assays}

Plasmids containing either the $X$. laevis major oocyte 5S rRNA gene (pXP5Soo) or the somatic 5S rRNA gene (pSP64-X1s11; Guinta et al. 1986) were linearized with HindIII and BamHI, respectively. Unlabeled antisense RNA was generated using either SP6 RNA polymerase (pXP64-X1s11) or T7 RNA polymerase (pSP5Soo).

RNase protection experiments were performed according to the protocol RPA11 (Ambion, Austin, TX). Briefly, $400 \mathrm{ng}$ of unlabeled antisense RNA were mixed with one-fifth of the radiolabeled RNA synthesized in an in vitro run-on transcription of embryonic chromatin (see above). After an overnight hybridization in $80 \%$ formamide, $100 \mathrm{~mm}$ sodium citrate $(\mathrm{pH} 6.4), 300$ mM sodium acetate ( $\mathrm{pH} 6.4$ ), and $1 \mathrm{mM}$ EDTA, the samples were digested with a mixture of RNase $\mathrm{T} 1$ and RNase $A(10 \mu \mathrm{g} / \mathrm{ml})$ for $30 \mathrm{~min}$ at $37^{\circ} \mathrm{C}$. The reaction was stopped by precipitation with ethanol. RNAs were resolved on a $6 \%$ polyacrylamide gel (see Guinta et al. 1986; Andrews et al. 1991).

\section{Electrophoretic and immunochemical analyses of proteins}

Polyacrylamide SDS-electrophoresis was performed as described by Laemmli (1970). Two-dimensional electrophoresis was carried out essentially as described by Russanova et al. $(1980)$. Briefly, the proteins were first separated in a $15 \%$ polyacrylamide slab gel containing $7 \mathrm{~m}$ urea and $5 \%$ acetic acid. The strip with the separated proteins was then excised and placed on top of a second gel, which was made of a $3-\mathrm{cm} 5 \%$ stacking gel and $15-\mathrm{cm}$ separating gel, containing $0.4 \%$ Triton X-100 and $6 \mathrm{M}$ urea. Usually, electrophoresis was run for $14-16 \mathrm{hr}$ at $7 \mathrm{~mA}$. For identification of the tritium-labeled histones, the gels were first stained with $0.1 \%$ Coomassie Brilliant Blue R-250 (Bio-Rad) to determine the positions of the unlabeled carrier histones, which served as markers, destained, treated for 15-30 min with Amplify (Amersham), dried, and autoradiographed.

Polyclonal antibodies against $X$. laevis $\mathrm{Hl}, \mathrm{B} 4$, and TFIIIA were prepared after injection of the proteins into rabbits (An- 
drews and Brown 1987; Wolffe 1989b; Dimitrov et al. 1993). The antibodies were immunospecifically purified from IgG by affinity chromatography with antigen conjugated to $\mathrm{CNBr}-\mathrm{Sepha}$ rose (Harlow and Lane 1988). All Western blots were made by standard methods (Harlow and Lane 1988), and they were visualized using India ink before incubation with the antibody to ascertain transfer. Purified TFIIIA (Smith et al. 1984) and histone $\mathrm{H} 1$ (Wolffe 1989b) were used as standards.

\section{Acknowledgments}

We thank Drs. Rosamund Smith, Eva Dworkin-Rastl, and Harald Kandolf for communicating results prior to publication. We are grateful to Dr. Matt Andrews for plasmid DNAs. We thank Drs. Geneviève Almouzni, Jeffrey Hayes, Tim O'Neill, and Robert Simpson for a critical reading and Ms. Thuy Vo for preparation of the manuscript. Philippe Bouvet is supported by an European Molecular Biology Organization long-term fellowship.

The publication costs of this article were defrayed in part by payment of page charges. This article must therefore be hereby marked "advertisement" in accordance with 18 USC section 1734 solely to indicate this fact.

\section{References}

Adams, C.C. and J.L. Workman. 1993. Nucleosome displacement in transcription. Cell 72: 305-308.

Allan, J., P.G. Hartman, C. Crane-Robinson, and F.X. Aviles. 1980. The structure of histone $\mathrm{Hl}$ and its location in chromatin. Nature 288: 675-679.

Almouzni, G., M. Méchali, and A.P. Wolffe. 1990. Competition between transcription complex assembly and chromatin assembly on replicating DNA. EMBO J. 9: 573-582.

- 1991. Transcription complex disruption caused by a transition in chromatin structure. Mol. Cell. Biol. 11: 655665.

Andrews, M.T. and D.D. Brown. 1987. Transient activation of oocyte 5S RNA genes in Xenopus embryos by raising the level of the trans-acting factor TFIIIA. Cell 51: 445-453.

Andrews, M.T., S. Loo, and L.R. Wilson. 1991. Coordinate inactivation of class III genes during the gastrula-neurula transition in Xenopus. Dev. Biol. 146: 250-254.

Aubert, D., M. Garcia, M. Benchaibi, D. Poncet, Y. Chebloune, G. Verdier, V. Nigon, J. Samarut, and C.V. Mura. 1991. Inhibition of proliferation of primary avian fibroblasts through expression of histone $\mathrm{H} 5$ depends on the degree of phosphorylation of the protein. I. Cell Biol. 113: 497-506.

Bogenhagen, D.F. and D.D. Brown. 1981. Nucleotide sequences in Xenopus 5S DNA required for transcription termination. Cell 24: 261-270.

Braunstein, M., A.B. Rose, S.G. Holmes, C.D. Allis, and J.R. Broach. 1993. Transcriptional silencing in yeast in associated with reduced histone acetylation. Genes \& Dev. 7: 592604.

Brown, D.D. and M.S. Schlissel. 1985. A positive transcription factor controls the differential transcription of two 5S RNA genes. Cell 42: 759-767.

Butler, P.J.G. and J.O. Thomas. 1980. Changes in chromatin folding in solution. J. Mol. Biol. 140: 505-529.

Chipev, C.C. and A.P. Wolffe. 1992. Chromosomal organization of Xenopus laevis oocyte and somatic 5S rRNA genes in vivo. Mol. Cell. Biol. 12: 45-55.

Clark, D.J. and A.P. Wolffe. 1991. Superhelical stress and nucleosome mediated repression of 5S RNA gene transcription in vitro. EMBO I. 10: 3419-3428.
Clark, H.J., C. Oblin, and M. Bustin. 1992. Developmental regulation of chromatin composition during mouse embryogenesis: Somatic histone $\mathrm{Hl}$ is first detectable at the 4-cell stage. Development 115: 791-799.

Cotten, M. and M.L. Birnsteil. 1989. Ribozyme mediated destruction of RNA in vitro. EMBO J. 8: 3861-3866.

Croston, G.E., K.A. Kenigan, L.M. Lira, D.R. Marshak, and J.T. Kadonaga. 1991. Sequence specific antirepression of histone H1-mediated inhibition of basal RNA polymerase II transcription. Science 251: 643-649.

Dimitrov, S., G. Almouzni, M. Dasso, and A.P. Wolffe. 1993. Chromatin transitions during early Xenopus embryogenesis: Changes in histone $\mathrm{H} 4$ acetylation and in linker histone type. Dev. Biol. 160: 214-227.

Dworkin-Rastl, E., H. Kandolf, and R.C. Smith. 1994. The material histone $\mathrm{H} 1$ variant, H1M (B4 protein), is the predominant $\mathrm{Hl}$ histone in Xenopus pregastrula embryos. Dev. Biol. 161: 425-439.

Engelke, D.R., S.Y. Ng, B.S. Shastry, and R.G. Roeder. 1980. Specific interaction of a purified transcription factor with an internal control region of 5S RNA genes. Cell 19: 717-728.

Felsenfeld, G. 1992. Chromatin: An essential part of the transcriptional apparatus. Nature 355: 219-224.

Gottesfeld, J.M. and L.S. Bloomer. 1980. Non random alignment of nucleosomes on 5S RNA genes of Xenopus laevis. Cell 21: 751-760.

Grunstein, M. 1990. Histone function in transcription. Annu. Rev. Cell Biol. 6: 643-678.

Gruss, C., C. Gutierrez, W.C. Burhans, M.L. DePamphilis, T. Koller, and J.M. Sogo. 1990. Nucleosome assembly in mammalian cell extracts before and after DNA replication. EMBO J. 9: 2911-2922.

Guinta, D.R., J.Y. Tso, S. Narayanswami, B. Hamkalo, and L.J. Korn. 1986. Early replication and expression of oocyte $5 \mathrm{~S}$ RNA genes in a Xenopus somatic cell line carrying a translocation. Proc. Natl. Acad. Sci. 83: 5150-5154.

Gurdon, J.B., C. Dingwall, R.A. Laskey, and L.J. Korn. 1982. Developmental inactivity of 5S RNA genes persists when chromosomes are cut between genes. Nature 299: 652-653.

Harland, R.M. and L. Misher. 1988. Stability of RNA in developing Xenopus embryos and identification of a destabilizing sequence in TFIIIA messenger RNA. Development 102: 837-852.

Harlow, E. and D. Lane. 1988. Antibodies: A laboratory manual. Cold Spring Harbor Laboratory, Cold Spring Harbor, New York.

Haseloff, J. and W.L. Gerlach. 1988. Simple RNA enzymes with new and highly specific endoribonuclease activities. Nature 334: 585-591.

Hayes, J.I. and A.P. Wolffe. 1992. Histones H2A/H2B inhibit the interactions of transcription factor IIIA with the Xenopus borealis somatic 5S RNA gene in a nucleosome. Proc. Natl. Acad. Sci. 89: 1229-1233.

. 1993. Preferential and asymmetric interaction of linker histones with 5S DNA in the nucleosome. Proc. Natl. Acad. Sci. 90: 6415-6419.

Herskowitz, I., B. Andrews, W. Kruger, J. Ogas, A. Sil, C. Coburn, and C. Peterson. 1992. Integration of multiple regulatory inputs in the control of HO expression in yeast. In Transcriptional regulation /ed. S. McKnight and K. Yamamotol, Vol. 2, pp. 949-974. Cold Spring Harbor Laboratory Press, Cold Spring Harbor, New York.

Jerzmanowski, A. and R.D. Cole. 1990. Flanking sequences of Xenopus 5S RNA genes determine differential inhibiton by H1 histone in vitro. J. Biol. Chem. 265: 10726-10732.

Kamakaka, R.T., M. Bulger, and J.T. Kadonaga. 1993. Potentia- 
tion of RNA polymerase II transcription by Gal4-VP16 during but not after DNA replication and chromatin assembly. Genes \& Dev. 7: 1779-1795.

Kandolf, H. 1992. "Biological functions of histone H1 in early development of Xenopus laevis." Dissertation, Dipl.-Ing, Universität Wien, Germany.

Keller, H.J., P.J. Romaniuk, and J.M. Gottesfeld. 1992. Interaction of Xenopus TFIIIC with the TFIIIA 5S RNA gene complex. I. Biol. Chem. 267: 18190-18198.

Khochbin, S. and A.P. Wolffe. 1993. Developmental regulation and butyrate inducible transcription of the Xenopus histone $\mathrm{HI}^{\circ}$ promoter. Gene 128: 173-180.

Knowles, J.A., Z.C. Lai, and G.J. Childs. 1987. Isolation, characterization, and expression of the gene encoding the late histone subtype H1-gamma of the sea urchin Strongylocentrotus purpuratus. Mol. Cell. Biol. 7: 478-489.

Krieg, P.A. and D.A. Melton. 1984. Functional messenger RNAs are produced by SP6 in vitro transcription of cloned cDNAs. Nucleic Acids Res. 12: 7057-7070.

Laemmli, U.K. 1970. Cleavage of structural proteins during the assembly of the head of bacteriophage T4. Nature 227: 680685.

Lai, Z.C. and G. Childs. 1988. Characterization of the structure and transcriptional patterns of the gene encoding the late histone subtype $\mathrm{Hl}-\beta$ of the sea urchin Strongylocentrotus purpuratus. Mol. Cell. Biol. 8: 1842-1853.

Lassar, A.B., P.L. Martin, and R.G. Roeder. 1983. Transcription of class III genes: Formation of pre-initiation complexes. Science 222: $740-748$.

Laybourn, P.J. and J.T. Kadonaga. 1991. Role of nucleosome cores and histone $\mathrm{H} 1$ in regulation of transcription by RNA polymerase II. Science 254: 238-245.

Lee, D.Y., J.J. Hayes, D. Pruss, and A.P. Wolffe. 1993. A positive role for histone acetylation in transcription factor binding to nucleosomal DNA. Cell 72: 73-84.

Levy, S., I. Sures, and L. Kedes. 1982. The nucleotide and amino acid coding sequence of a gene for $\mathrm{H} 1$ histone that interacts with euchromatin. J. Biol. Chem. 257: 9438-9443.

Lin, S.-Y. and A.D. Riggs. 1975. The general affinity of lac repressor for E. coli DNA: Implications for gene regulation in procaryotes and eucaryotes. Cell 4: 107-111.

Majumder, S., M. Miranda, and M.L. DePamphilis. 1993. Analysis of gene expression in mouse preimplantation embryos demonstrates that the primary role of enhancers is to relieve repression of promoters. EMBO I. 12: 11431-11440.

Martinez-Salas, E., E. Linney, J. Hassell, and M.L. DePamphilis. 1989. The need for enhancers in gene expression first appears during mouse development with the formation of the $z y-$ gotic nucleus. Genes \& Dev. 3: 1493-1506.

Meersseman, G., S. Pennings, and E.M. Bradbury. 1991. Chromatosome positioning an assembled long chromatin-linker histones affect nucleosome placement on $5 \mathrm{~S}$ rDNA. J. Mol. Biol. 220: 89-100.

Newport, J.W. and M.W. Kirschner. 1982a. A major developmental transition in early Xenopus embryos. 1. Characterization and timing of cellular changes at the mid blastula stage. Cell 30: 675-686.

- 1982b. A major developmental transition in early Xenopus embryos. II. Control of the onset of transcription. Cell 30: 687-696.

Newrock, K.M., C.R. Alfageme, C.V. Nardi, and L.H. Cohen. 1977. Histone changes during chromatin remodeling in em. bryogenesis. Cold Spring Harbor Symp. Quant. Biol. 42: $421-431$.

Old, R.W., H.R. Woodland, J.E.M. Ballantine, T.C. Aldridge, C.A. Newton, W.A. Bains, and P.C. Turner. 1982. Organiza- tion and expression of cloned histone gene clusters from Xenopus laevis and X. broealis. Nucleic Acids Res. 10: 75617578.

Pelham, H.R.B. and D.D. Brown. 1980. A specific transcription factor can bind either the 5S RNA gene or 5S RNA. Proc. Natl. Acad. Sci. 77: 4170-4174.

Perry, M., G.H. Thomsen, and R.G. Roeder. 1985. The nucleotide sequence and genomic organization of two distinct tandemly repeated Xenopus laevis histone gene clusters. $/$. Mol. Biol. 185: 479-499.

Poccia, D. 1986. Remodeling of nucleoproteins during gametogenesis, fertilization and early development. Int. Rev. Cytol. 105: 1-83.

Renauld, H., O.M. Aparicio, P.D. Zierath, B.L. Billington, S.K. Chablani, D.E. Gottschling. 1993. Silent domains are assembled continuously from the telomere and are defined by promoter distance and strength, and by SIR3 dosage. Genes \& Dev. 7: 1133-1145.

Renz, M. and L.A. Day. 1976. Transition from non-cooperative to cooperative and selective binding of histone $\mathrm{Hl}$ to DNA. Biochemistry 15: 3220-3228.

Risley, M.S. and R.A. Eckhardt. 1981. H1 histone variants in Xenopus laevis. Dev. Biol. 84: 79-87.

Rodriguez-Campos, A., A. Shimamura, and A. Worcel. 1989. Assembly and properties of chromatin containing histone H1. I. Mol. Biol. 209: 135-150.

Rollins, M.B., S. Del Rio, A.L. Galey, D.R. Setzer, and M.T. Andrews. 1993. Role of TFIIIA zinc fingers in vivo: Analysis of single-finger function in developing Xenopus embryos. Mol. Cell. Biol. 13: 4776-4783.

Rupp, R.A.W. and H. Weintraub. 1991. Ubiquitous MyoD transcription at the midblastula transition precedes inductiondependent MyoD expression in presumptive mesoderm of X. laevis. Cell 65: 927-937.

Russanova, V., C. Venkov, and R. Tsanev. 1980. A comparison of histone variants in different rat tissues. Cell Differ. 9: 339-350.

Schlissel, M.S. and D.D. Brown. 1984. The transcriptional regulation of Xenopus 5S RNA genes in chromatin: The roles of active stable transcription complexes and histone H1. Cell 37: 903-913.

Segall, J., T. Matsui, and R.G. Roeder. 1980. Multiple factors are required for the accurate transcription of purified genes by RNA polymerase III. J. Biol. Chem. 255: 11986-11991.

Seidel, C.W. and L.J. Peck. 1992. Kinetic control of 5S RNA gene transcription. f. Mol. Biol. 227: 1009-1018.

Setzer, D.R. and D.D. Brown. 1985. Formation and stability of the 5S RNA transcription complex. I. Biol. Chem. 260: 2483-2492.

Shastry, B.S., B. Honda, and R.G. Roeder. 1984. Altered levels of a $5 \mathrm{~S}$ gene-specific transcription factor (TFIIIA) during oogenesis and embryonic development of Xenopus laevis. J. Biol. Chem. 259: 11373-11382.

Shimamura, A., D. Tremethick, and A. Worcel. 1988. Characterization of the repressed 5S DNA minichromosomes assembled in vitro with a high speed supernatant of Xenopus laevis oocytes. Mol. Cell. Biol. 8: 4257-4269.

Shimamura, A., M. Sapp, A. Rodriguez-Campos, and A. Worcel. 1989. Histone $\mathrm{Hl}$ represses transcription from minichromosomes assembled in vitro. Mol. Cell. Biol. 9: 5573-5584.

Simpson, R.T. 1978. Structure of the chromatosome, a chromatin core particle containing 160 base pairs of DNA and all the histones. Biochemistry 17: 5524-5521.

- 1991. Nucleosome positioning: Occurrence, mechanisms and functional consequences. Nucleic Acids Res. 40: 143-184. 
Smith, D.R., I.J. Jackson, and D.D. Brown. 1984. Domains of the positive transcription factor specific for the Xenopus $5 \mathrm{~S}$ RNA gene. Cell 37: 645-652.

Smith, R.C., E. Dworkin-Rastl, and M.B. Dworkin. 1988. Expression of a histone $\mathrm{Hl}$-like protein is restricted to early Xenopus development. Genes \& Dev. 2: 1284-1295.

Stutz, F., E. Gouilloud, and S.G. Clarkson. 1989. Oocyte and somatic tyrosine tRNA genes in Xenopus laevis. Genes \& Dev. 3: 1190-1198.

Sun, J.M., R. Wiaderkiewicz, and A. Ruiz-Carrillo. 1989. Histone $\mathrm{H} 5$ in the control of DNA synthesis and cell proliferation. Science 245: 68-71.

Tafuri, S.R. and A.P. Wolffe. 1993. Selective recruitment of masked maternal mRNA from messenger ribonucleoprotein particles containing FRGY2 (mRNP4). I. Biol. Chem. 268: 24255-24261.

Thoma, F., T. Koller, and A. Klug. 1979. Involvement of histone $\mathrm{H} 1$ in the organization of the nucleosome and if the salt dependent superstructures of chromatin. I. Cell Biol. 83: $407-427$.

Thomas, J.O. and C. Rees. 1983. Exchange of histones $\mathrm{H} 1$ and H5 between chromatin fragments: A preference of $\mathrm{H} 5$ for higher order structures. Eur. J. Biochem. 134: 109-115.

Tremethick, D., D. Zucker, and A. Worcel. 1990. The transcription complex of the 5S RNA gene, but not transcription factor TFIIIA alone, prevents nucleosomal repression of transcription. J. Biol. Chem. 265: 5014-5023.

Turner, B.M. 1993. Decoding the nucleosome. Cell 75: 5-8.

van Holde, K.E. 1989. Chromatin, pp. 268-273. Springer-Verlag, Berlin.

Wakefield, L. and J.B. Gurdon. 1983. Cytoplasmic regulation of 5S RNA genes in nuclear-transplant embryos. EMBO $/$. 2: 1613-1619.

Wallace, R.A., D.W. Jared, J.N. Dumont, and M.W. Sega. 1973. Protein incorporation by isolated amphibian oocytes. II. Optimum incubation conditions. J. Exp. Zool. 184: 321-334.

Weintraub, H. 1978. The nucleosome repeat length increases during erythropoiesis in the chick. Nucleic Acids Res. 5: 1179-1188.

1984. Histone H1-dependent chromatin superstructures and the suppression of gene activity. Cell 38: 17-27.

Winston, F. and M. Carlson. 1992. Yeast SNF/SWI transcriptional activators and the SPT/SIN chromatin connection. Trends Genet. 8: 387-391.

Wolffe, A.P. 1988. Transcription fraction TFIIIC can regulate differential Xenopus 5S RNA gene transcription in vitro. EMBO I. 7: 1071-1079.

- 1989a. Transcriptional activation of Xenopus class III genes in chromatin isolated from sperm and somatic nuclei. Nucleic Acids Res. 17: 767-780.

- 1989b. Dominant and specific repression of Xenopus oocyte 5S RNA genes and satellite I DNA by histone $\mathrm{Hl}$. EMBO I. 8: 527-537.

- 1992. Chromatin: Structure and function. Academic Press, San Diego, CA.

Wolffe, A.P. and D.D. Brown. 1987. Differential 5S RNA gene expression in vitro. Cell 51: 733-740.

1988. Developmental regulation of two 5 S ribosomal RNA genes. Science 241: 1626-1632.

Wolffe, A.P., E. Jordan, and D.D. Brown. 1986. A bacteriophage RNA polymerase transcribes through a Xenopus 5S rRNA gene transcription complex without disrupting it. Cell 44: 381-389.

Woodland, H.R., J.M. Flynm, and A.J. Wyllie. 1979. Utilization of stored mRNA in Xenopus embryos and its replacement by newly synthesized transcripts: Histone $\mathrm{H} 1$ synthesis using interspecies hybrids. Cell 18: 165-171.

Worcel, A., S. Han, and M.L. Wong. 1978. Assembly of newly replicated chromatin. Cell 15: 969-977.

Wormington, W.M. and D.D. Brown. 1983. On set of 5S RNA gene regulation during Xenopus embryogenesis. Dev. Biol. 99: 248-257.

Wormington, W.M., D.F. Bogenhagen, E. Jordan, and D.D. Brown. 1981. A quantitative assay for Xenopus 5S rRNA gene transcription in vitro. Cell 24: 809-817.

Young, D. and D. Carroll. 1983. Regular arrangement of nucleosomes on 5S rRNA genes in Xenopus laevis. Mol. Cell. Biol. 3: 720-730. 


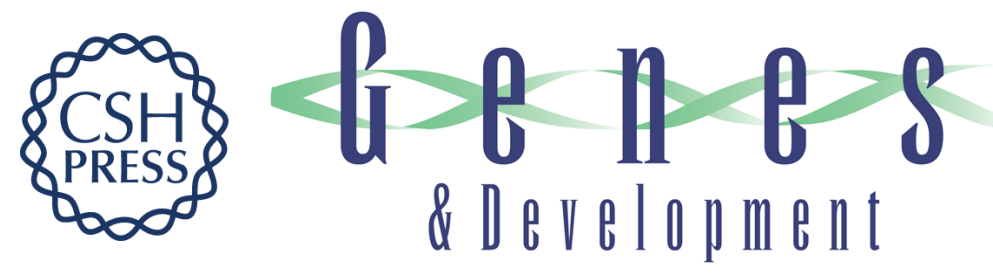

\section{Specific regulation of Xenopus chromosomal 5S rRNA gene transcription in vivo by histone $\mathrm{H} 1$.}

P Bouvet, S Dimitrov and A P Wolffe

Genes Dev. 1994, 8:

Access the most recent version at doi:10.1101/gad.8.10.1147

References This article cites 92 articles, 34 of which can be accessed free at:

http://genesdev.cshlp.org/content/8/10/1147.full.html\#ref-list-1

License

Email Alerting

Service

Receive free email alerts when new articles cite this article - sign up in the box at the top right corner of the article or click here.

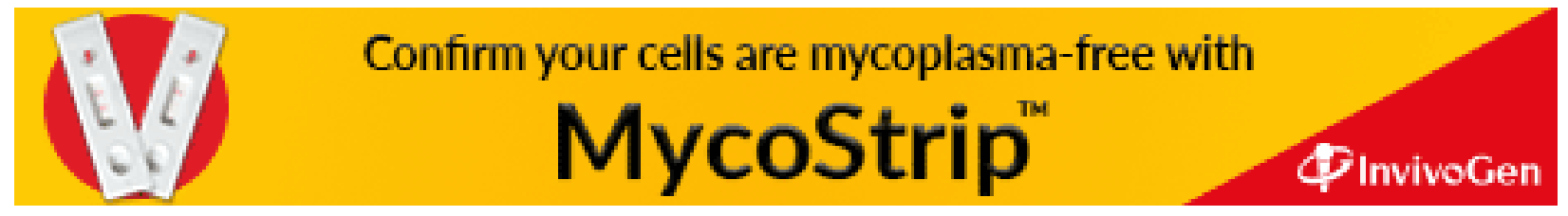

